\title{
The Camels in Balochistan: Status, farming practices and camel centered measures
}

\author{
Illahi Bakhsh Marghazani ${ }^{*}$, Masood Ul Haq Kakar ${ }^{1}$, Muhammad \\ Umar $^{1}$, Farooq Ahmed Luni ${ }^{2}$, Muhammad Saleem ${ }^{3}$, Khalid Hamayoon ${ }^{2}$ \\ and Jan Muhammad Safi ${ }^{2}$ \\ 1. Faculty of Veterinary and Animal Sciences, Lasbela University of Agriculture, Water \& Marine Sciences, Uthal- \\ Pakistan \\ 2. Livestock and Dairy Development Department, Balochistan-Pakistan \\ 3. Food Department, Balochistan-Pakistan \\ *Corresponding author's email: marghazani76@yahoo.com
}

Citation

Illahi Baksh Marghazani, Masood Ul Haq Kakar, Muhammad Umar, Farooq Ahmed Luni, Muhammad Saleem, Khalid Hamayoon and Jan Muhammad Safi. The Camels in Balochistan: Status, farming practices and camel centered measures Pure and Applied Biology. Vol. 8, Issue 1, pp503-508. http://dx.doi.org/10.19045/bspab.2018.700209

\begin{tabular}{llll}
\hline \hline Received: 20/10/2018 & Revised: 03/12/2018 & Accepted: 06/12/2018 & Online First: 12/12/2018 \\
\hline \hline
\end{tabular}

\section{Abstract}

This study is based on primary and secondary data encompassing status of camels and camel farmers, prevailing farming practices and camel centered measures in Balochistan, Pakistan. The key purpose is to give a glimpse to the policy makers about this neglected species that is bestowed with unearthed potentials. The province Balochistan has the lion's share (41\%) of total camel population of Pakistan. The documented breeds in this region are seven out of total twenty breeds in Pakistan. The study explains that the camel famers are illiterate and living ultra low level life standards. The camel farming is on traditional pattern. Grazing has poor nutritive value resulting in delayed growth, puberty age, conception rate, increased calving interval and low milk yield. Milk marketing is not favored coupled with lack of market knowledge for selling live camels. The academic and administrative focus on camel's research and development is rare at all levels. It is high time to work on camel, camel farmer and camel farming with multi-pronged strategy. Educating camel farmers in field schools and adoption of scientific farming procedures, milk and meat marketing, value addition of milk and dairy products are the ways to move forward.

Keywords: Balochistan; Camel; Farming; Poverty; Trends

\section{Introduction}

The world camel population is estimated 27.104 million heads. The one humped dromedary camels (Camelus dromedarius) are more in numbers (24.167 million) than two-humped camels (Camelus bactrianus) which are approximately 2.0 million in numbers [1]. Pakistan ranks eighth major camel populous countries of the world [2].
The camel despite of healthy total strength of 1.1 million [3] and God gifted natural potentials of milk and meat production is scaled less and even negligible whether by camel farmers themselves or livestock policy makers at provincial and national levels in Pakistan. The camel farmers remain deprived of true income potential of the camel and hence hang around in vicious cycle of 
poverty. In camel heads, Balochistan province has major share of approximately (41\%), followed by Sindh (30\%), Punjab (22\%) and KPK (7\%) respectively. Except Balochistan, the rest regions of Pakistan are showing declining trend in camel heads. Despite of this unearthed camel wealth, the studies on camel farmer, camel farming practices, feeding and management are deficient particularly in Balochistan. In this manuscript, it is tried to portray the significance of Balochistan as a hub of camelid in Pakistan and to have glance over the present status of camel and camel centered measures in Balochistan.

\section{Materials and methods}

Primary data collected from preliminary studies conducted in livestock communities at small scale using questionnaire. The primary data also included interviews from camel farmers consisting of camel breeds, literacy level, farming practices, camel preferred rangeland plants, milk yield and marketing means. The samples of camel preferred rangeland species as indicated by camel farmers were subjected to laboratory analysis such as proximate analysis [4] to know the dry matter, crude protein and fiber contents. All sources of primary data were analyzed using statistical package for social sciences (SPSS) in order to obtain a preliminary picture (strength scale) regarding camels, camel farming and camel related socio-economic impacts. In addition to that, secondary data (Economic Survey of Pakistan, Agriculture Statistics, Livestock Census) remodeled to have glance over the trends in camel population and milk yield. In milk yield and population trends, the percent share of Balochistan province was calculated using average share of Balochistan (41\%) from the total camel population of the country.

\section{Results and discussion}

The status of camel and camel centered activities in Balochistan are given in (Table
1) whilst the estimated camel population and milk yield trends (Livestock censes, ESP 2016-17) are given in (Figure 1 and 2) respectively. The camel has significant socioeconomic importance [5]. The population and milk yield potential are encouraging indicators in Balochistan province. The widespread geographical area $(3,47,190$ sq.km) and diversity in ecological zones (six) of Balochistan are among the major factors contributing to the healthy population of camels. Of the twenty recognized breeds of Pakistan, seven breeds are documented in Balochistan named Brahvi, Kachhi, Kharani, Lassi, Makrani, Pishin and Rodbari [6, 7]. In Balochistan, the use of camel is traditional i.e., carrying fire woods in small cities, transporting bricks as pulling carts in big cities and household luggage transporting source during nomadic voyage. The negligible use is also observed for children and visitors/tourists riding during Eid occasions and at coastal beaches, respectively. The efforts to involve camel farmer and farming on modern lines are insignificant. There are three major camel husbandry practices observed like small ruminants productions systems of Balochistan i.e., the sedentary (settled/nonmoving) camel husbandry, Transhumant (partially/seasonal moving) camel husbandry and nomadic (all time moving/opportunist) camel husbandry system. Similar type of camel production systems are reported in earlier literature [8]. The sedentary camel raising system is the major camel husbandry system in Balochistan. The camel community is dominantly illiterate, facing socioeconomic challenges and living in ultra-low level life standards. The knowhow/awareness to gain more economic returns from their ancestral camel farming practices is lacking. The average milk yield of camel breeds of Balochistan varies from 2-5 liters per day. This average yield is in line with the earlier findings [9] who reported that the average 
milk production of Pakistani camel is 1894.93 liters per lactation, with the daily yield of 4.25 liter. It is worth mentioning that the sale of camel milk is considered a forbidden practice by camel farmer's community in Balochistan. On the other hand, it is well recorded that camel milk fetches more money than other livestock species due to its medicinal properties along with nutritional contents. It is lesser in fat and lactose contents, and more in vitamin $\mathrm{C}$, potassium, and iron [10]. The average chemical properties of camel milk for the total solid, protein, fat, ash, lactose content and acidity are $13.62 \%, 4.35 \%$, fat $4.59 \%$, ash 0.84 , lactose $3.79 \%$ and 0.19 , respectively [11]. In mega markets, the camel milk is sold at Rs. 200-350 per liter, but camel farmers are either not selling or selling this product at very low price. In this context, focusing only on developing awareness and linking marketing channels can bring a significant change in poverty alleviation of camel farmers. Further, concentrating on developing value added camel milk products can share more returns and employment generation. In recent years, the commercial utilization of camel milk has grown greatly particularly in the context of urbanization [12]. The major threats in camel milk marketing are poor hygienic quality, lack of milk processing technologies and availability of rich quantity of camel milk. Further, lack of poor camel milk marketing and infrastructure adversely influence shelf life of camel milk. It reduces sales and income to the camel farmers. If marketing model is improved it may positively enrich both; the camel farmer and the consumer. It is reported that with packaging and more investment in camel milk production, camel's milk could become a 10 billion dollar annual global industry [13].

The camel prefers variety of plants i.e., trees and shrubs. These species also consumes other naturally growing plants of desert or semi desert regions that may be bitter in taste, thorny and salty in nature [14].The camel farmers of Balochistan lack basic concept of balanced feeding to their camels. The conventional feeding pattern based on grazing (deficient in energy and protein contents) is highly practiced. The camels are let stray to maintain and grow themselves on available natural vegetation. It is deduced from the camel husbandry practices that the poor feeding is resulting in delayed growth, puberty age, conception rate and an increase in calving interval, thus resulting in poor economic returns. However, due to shift in demand and urbanization, there is an urgent need to establish ways of improving the nutritional conditions of the camels in order to increase milk production [15] and thereby improving the life of camel producers [16]. In this context, a study conducted to know the effect of concentrate supplementation to free ranging dromedary camels and it was found that increasing supplementation increased milk yield in camels [17].

The camel meat markets are gradually getting developed in cities which are good sign for developing camel market at regional level. On the other hand, such markets are open at international level however; means to access those markets and fulfilling the export criteria require concrete steps both at governmental and private levels. Any difficulty in market access will restrict opportunities for income generation [18]. Therefore, it is of prime importance to enhance marketing accessibility, capacity building and development of farmers to reach markets and engage them in marketing activities.

The research on enhancing milk and meat yields in local camel breeds of Balochistan is ruthlessly deficient. The responsible organizations/government departments and academic institutes/universities particularly Lasbela University of Agriculture, Water and Marine Sciences and Livestock and Dairy 
Development Department of the province along with non-government organizations require to chalk out comprehensive strategy focusing camel research, shift in conventional camel farming practices and developing market interventions.

Table 1. Camel and camel centered activities status in Balochistan

\begin{tabular}{|c|c|}
\hline Description & Strength \\
\hline Camel heads & ++++ \\
\hline Camel breeds & ++++ \\
\hline Camel farmer literacy level & + \\
\hline Camel farmers economic condition & + \\
\hline Sedentary camel husbandry & +++ \\
\hline Transhumant camel husbandry & ++ \\
\hline Nomadic camel husbandry & + \\
\hline Camel milk marketing & ++ \\
\hline Camel meat marketing & + \\
\hline Camel farming tradition to modernity trend & ++ \\
\hline Camel centered research at university level & + \\
\hline Camel centered research at provincial government level & + \\
\hline Initiatives by Non-Governmental organizations & + \\
\hline
\end{tabular}

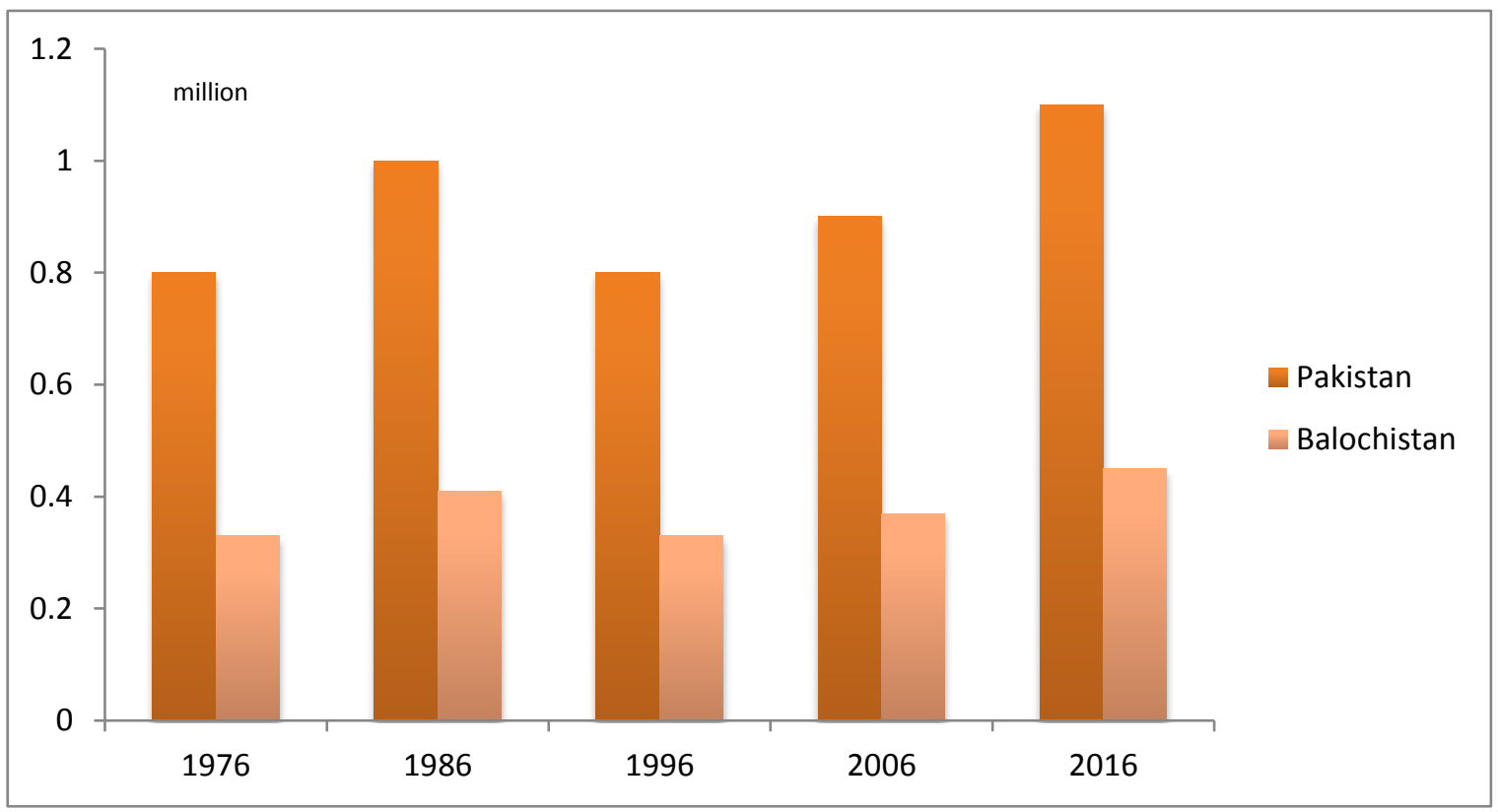

Figure 1. Camel population trend in Pakistan and estimated share of Balochistan 


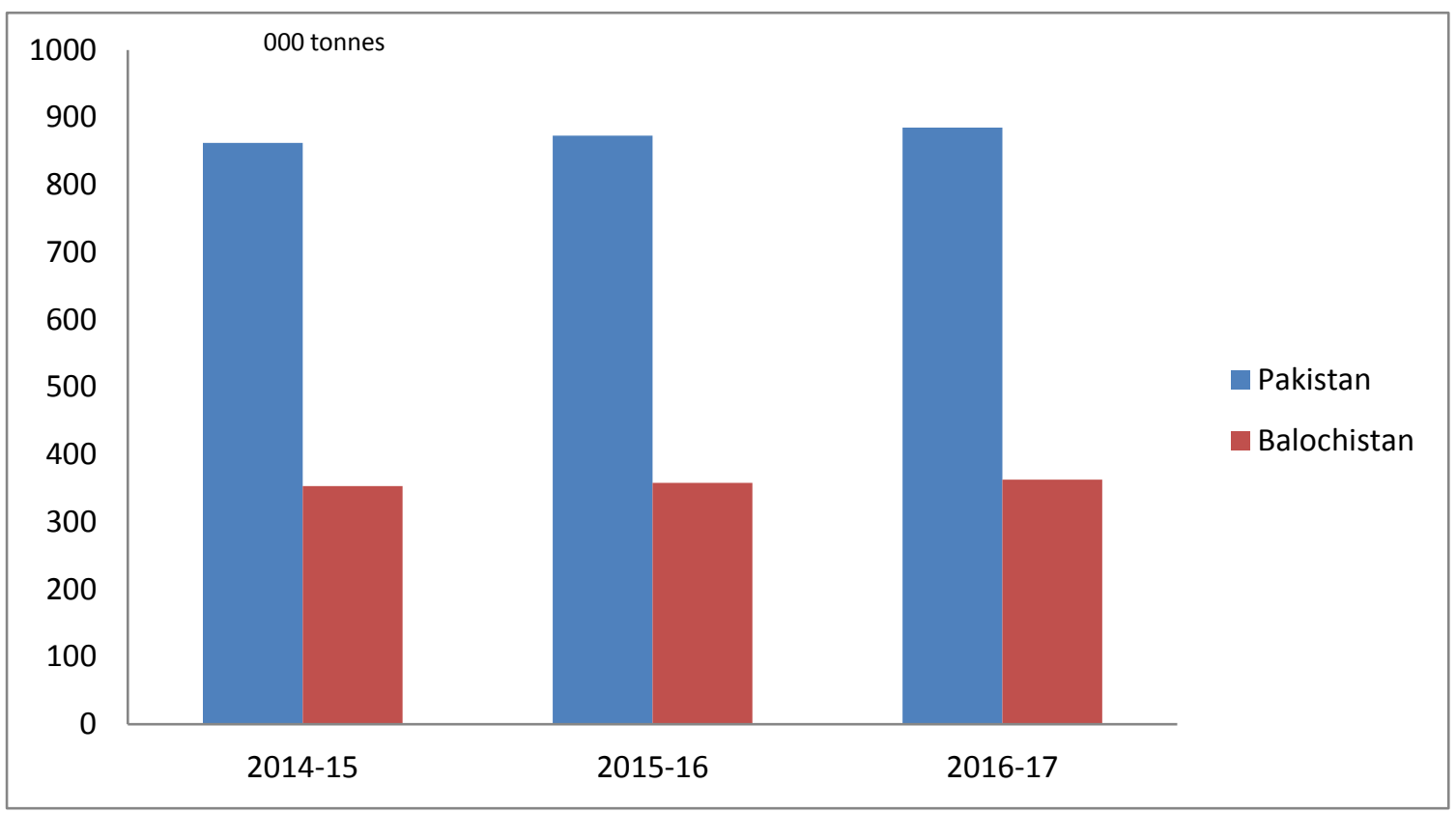

Figure 2. Camel milk yield trend in Pakistan and estimated share of Balochistan

\section{Conclusion}

In Balochistan, it is high time to concentrate camel centered strategies with multi-pronged approaches. Educating farmers, camel feeding and management, increasing milk yield, value addition of dairy products and developing market links are the ways to move forward. There is dire need that all sectors work on collaborative strategy in order to drag camel and camel farmer form the socioeconomic collapse and its sponge down from landscape of the nature.

\section{Authors' contributions}

Conceived and designed the experiments: IB Marghazani, Performed the experiments: IB Marghazani, FA Luni, K Hamyoon \& JM Safi, Analyzed the data: M Umar \& M Saleem, Contributed materials/ analysis/ tools: MH Kakar \& M Saleem, Wrote the paper: IB Marghazani \& M Umar.

\section{References}

1. FAO (2013). FAOSTAT DATA, Statistics Division.

2. FAO (2010). Food and Agriculture Organization. FAOSTAT. FAO Statistics Division.
3. ESP (2016-17). Economic Survey of Pakistan. Economic Advisor's Wing. Ministry of Finance Govt. Pak. Islamabad, Pakistan.

4. AOAC (2000). Association of official analytical chemists. Official methods of analysis, $17^{\text {th }}$ ed., Washington, DC, USA.

5. Raziq A (2009). Portrayal of camelids in pastoral economy of north-eastern herders of Balochistan. PhD Diss., Deptt. Livestock Management, Univ. Agri Faisalabad, Pakistan.

6. Isani GB \& Baloch MN (2000). Camel breeds of Pakistan. The camel applied research and development network (CARDN), NADRI, Islamabad, Pakistan.

7. Younus M \& Iqbal A (2001). The handbook of Cholistan, Islamia Univ, Bahawalpur, Pakistan.

8. Asim F, Iqbal MM, Lateef M, Yaqoob M \& Younas M (2013). Production potential of camel and its prospects in Pakistan. Punjab Univ J Zool 28 (2): 8995. 
9. Baloch MN (2001). Documentation and characterization of camel breeds of Pakistan. PhD Diss. Sindh Agricultural Univ, Tandojam.

10. Konuspayeva G, Faye B \& Loiseau G (2009). The composition of camel milk: a meta-analysis of the literature data. $J$ Food Composition and Analysis 22(2): 95-101.

11. Idrees EM, Ishag IA \& Eisa MO (2016). Factors Affecting Chemical Properties of Camel Milk. Scientia 16(2): 49-53.

12. Matofari JW, Shalo PL, Younan M, Nanua NJ, Adongo A, Qabale \& Misiko BN (2013). Analysis of microbial quality and safety of camel (Camelus dromedarius) milk chain and implications in Kenya. J Agric Ext and Rural Dev 5(3): 50-54.

13. FAO (2012). Decent rural employment for food security: a case for action. Rome.

14. Field CR (2005). Where there is no Development Agency. A manual for Pastoralists and their Promoters. Natural
Resources International, Aylesford, Kent, UK. pp 260.

15. Al-Saiady MY, Mogawer HH, Faye B, Al-Mutairi SE, Bengoumi M, Musaad A \& Gar Elnaby A (2012). Some factors affecting dairy she-camel performance. Emirates Journal of Food and Agriculture 24(1): 85.

16. Wilson RT (1998). The nutritional requirements of camel. Options Méditerranéennes (CIHEAM). Série (2): 17-117 9.

17. Dereje M \& Udén P (2005). The browsing dromedary camel: II. Effect of protein and energy supplementation on milk yield. Animal Feed Sci.and Tech 121(3): 309-317.

18. Ahmed MM, Bezabih E, Jabbar MA, Tangka F \& Ethuni S (2003). Economic and nutritional impacts of marketoriented dairy production in the Ethiopian highland. Socio-economics and policy Research Working paper 51, ILRI (Int Livest Res Inst), Nairobi, Kenya pp 27. 